provoked by social stress. In these cases quick sociotherapeutic and psychotherapeutic intervention can sometimes obviate the need for admission to hospital, provided this intervention is supported by medication. In such circumstances it is imperative that the patient does in fact receive the drug prescribed.

Intramuscular injection of long-acting neuroleptics has the advantage of being the only mode of administration which gives absolute certainty that the drug does reach its proper place. Moreover, the magic "charge" of the syringe exceeds that of a tablet. But oral medication has the advantage over parenteral administration of being much more manageable for "field workers" (social psychiatrists and general practitioners). It is therefore of importance that a long-acting oral compound is now available besides the long-acting neuroleptics for injection.

\section{References}

Baro, F., Brugmans, J., Dom, R., and Lommel, R. van (1970). Fournal of Clinical Pharmacology, 10, 330.

Bobon, J., Melon, J., Mormont, C., Dufrasne, M., and Pinchard, A. (1970). Acta Psychiatria Belgica, 70, 523.

British Medical fournal, 1971, 1, 189.

Janssen, P. A. J., et al. (1970). Arzneimittel-Forschung, 20, 1689.

Janssen, P. A. J., et al. (1971). European fournal of Pharmacology. To be published.

Lowther, J. (1969). British fournal of Psychiatry, 115, 691

Praag, H. M. van, et al. (1970). Psychiatria, Neurologia, Neurochirurgia, 73, 165.

Prien, R. F., Cole, J. O., and Belkin, N. F. (1969). British fournal of Psychiatry, 115, 679 .

Renton, C. A., Affleck, J. W., Carstairs, G. M., and Forrest, A. D. (1963). Acta Psychiatrica Scandinavica, 39, 548 .

Smedt, R. de., Rodrigus, E., Debandt, R., and Brugmans, J. (1970). Fournal of Clinical Pharmacology, 10, 207

Wing, J. K. (1961). Fournal of Mental Science, 107, 862.

\title{
Exchange Transfusion with Dextran 40 in Polycythaemia Secondary to Hypoxic Lung Disease
}

\author{
B. D. W. HARRISON, R. J. GREGORY, T. J. H. CLARK, G. W. SCOTT
}

British Medical fournal, 1971, 4, 713-716

\section{Summary}

In eight patients with polycythaemia secondary to hypoxic lung disease 10 elective exchange transfusions were performed to reduce red cell mass, packed cell volume (P.C.V.), and whole blood viscosity. The rationale for reducing P.C.V. is discussed. It is concluded that patients with P.C.V. of $60 \%$ or over will benefit from exchange transfusion and that most patients with P.C.V. over $50 \%$ and true polycythaemia will also benefit. We also confirm that the technique of exchange transfusion is a rapid, safe, and effective method of achieving large venesections and reducing red cell mass.

\section{Introduction}

In the past various methods have been used to treat polycythaemia which is secondary to lung disease in an attempt to lessen its harmful effects. Venesection occasionally gives some relief (Auchincloss and Duggan, 1957) but leads to a temporary increase in clotting tendency with an added risk of thrombosis and embolism. Continuous oxygen therapy has been successful in reducing red cell mass and packed cell volume (P.C.V.) with symptomatic benefit but ordinarily necessitates a hospital stay of about six weeks (Chamberlain and Millard, 1963). Pyrimethamine with dapsone or phenylhydrazine has also been used and produced symptomatic improvement, but these drugs carry the risk of thrombocytopenia and overcorrection of the polycythaemia (Pengelly, 1966, 1969).

A method of rapidly lowering red cell volume by using an isovolaemic exchange transfusion technique has recently been described (Gregory, 1971a) and initial results in patients with

\section{Guy's Hospital, London S.E.1}

B. D. W. HARRISON, M.B., M.R.C.P., Junior Registrar, Cardiac Department (Present appointment: Registrar, Medical Unit, Westminster Hospital, London S.W.1)

T. J. H. CLARK, M.D., M.R.C.P., Consultant Physician, and Consultant Physician, Brompton Hospital, London S.W. 3

G. W. SCOTT, M.D., F.R.C.P., Consultant Physician

Princess Elizabeth Hospital, Guernsey, Channel Islands

R. J. GREGORY, D.A., M.R.C.P., Physician and General Practitioner secondary polycythaemia were very encouraging (Gregory, 1971b). Further experience with the method is now reported.

\section{Patients and Methods}

Ten elective isovolaemic exchange transfusions were performed in eight patients with polycythaemia secondary to hypoxic lung disease. The technique (Gregory, 1971a) consists in the simultaneous intravenous infusion of dextran 40 in $5 \%$ dextrose into one arm and venesection from the other arm. The total volume of dextran infused is equal to the volume of blood venesected, but only half is given during the period of the venesection, because low-molecular-weight dextran attracts an additional volume of fluid equal to its own volume from the extravascular space into the circulation. The remaining dextran is given over the next 8 to 16 hours.

The reason for using dextran 40 is primarily because it is an effective plasma expander, and with this technique 2 litres of blood can be safely removed in about 45 minutes. It also has the theoretical advantages of reducing red cell aggregation and, because it is hypertonic and draws fluid into the vascular space from the interstitial space, of improving tissue capillary blood flow.

All eight patients had a long history of respiratory illness with several previous admissions to hospital; all except one (Case 5) had a history of ankle swelling and raised jugular venous pressure. Their clinical and other data are given in Table I. Chronic bronchitis was defined according to the Medical Research Council (1965) classification, and emphysema was diagnosed on posteroanterior and lateral chest radiographs, the criteria of Laws and Heard (1962) being used. In none had there been any change in the symptoms or signs of their pulmonary or cardiac condition in the week preceding the study, and the weight of each patient measured daily had remained steady during that week. Two patients (Cases 4 and 6 ) were admitted on two occasions for exchange transfusion.

Red cell volume was measured with chromium-51-labelled red cells and whole blood, and plasma volumes were either estimated indirectly from this (Cases 1-5) or measured directly with iodine-125-labelled albumin (Cases 6-8). The results are expressed in millilitres per kilogramme of body weight. Whole blood viscosity was estimated on heparinized venous blood in vitro with a capillary viscometer and the results are expressed in centipoise. Arterial blood was obtained by brachial artery 

TABLE I-Clinical Details, Spirometric Volumes, and Volumes of Exchange
Transfusion in Each Patient

\begin{tabular}{|c|c|c|c|c|c|}
\hline $\begin{array}{l}\text { Case } \\
\text { No. }\end{array}$ & $\begin{array}{l}\text { Age } \\
\text { and }\end{array}$ & Diagnosis & $\mathrm{FEV}_{1}$ & FVC & $\begin{array}{c}\text { Volume } \\
\text { Exchanged }\end{array}$ \\
\hline & & & \multicolumn{3}{|c|}{ Litres } \\
\hline 1 & $57 \mathrm{~F}$. & Chronic obstructive bron- & & & \\
\hline & & $\begin{array}{l}\text { chins. Kadorogical empny- } \\
\text { sema }\end{array}$ & 0.8 & 1.75 & $1 \cdot 0$ \\
\hline 2 & $60 \mathrm{M}$. & Chronic obstructive bron- & $1 \cdot 3$ & 2.5 & 1.5 \\
\hline 3 & $58 \mathrm{~F}$. & $\begin{array}{l}\text { Chronic obstructive bron- } \\
\text { chitis. Radiological emphy- } \\
\text { sema }\end{array}$ & 0.4 & 1.4 & \\
\hline 4 & $48 \mathrm{M}$. & Radiological emphysema $\ldots$ & $0 \cdot 7$ & 1.5 & \} $\begin{array}{l}\text { (a) } 2 \cdot 0 \\
\text { (b) } 1 \cdot 5\end{array}$ \\
\hline 5 & & $\begin{array}{cccc}\text { Chronic } & \text { obstructive } & \text { bron- } \\
\text { chitis } & . . & \ldots & \ldots\end{array}$ & 0.7 & 1.8 & $1 \cdot 2$ \\
\hline 6 & $49 \mathrm{~F}$. & $\begin{array}{l}\text { Previous right artificial pneu- } \\
\text { mothoraces and left upper } \\
\text { lobe resection and left } \\
\text { thoracoplasty for pulmonary } \\
\text { tuberculosis. Chronic ob- } \\
\text { structive bronchitis }\end{array}$ & 0.7 & $1 \cdot 2$ & $\begin{array}{l}\text { (a) } 2.0 \\
\text { (b) } 1.5\end{array}$ \\
\hline 7 & & $\begin{array}{l}\text { Paralysed right diaphragm } \\
\text { after phrenic crush. Alveolar } \\
\text { hypoventilation }\end{array}$ & 1.4 & $2 \cdot 0$ & 2.0 \\
\hline 8 & $63 \mathrm{M}$. & 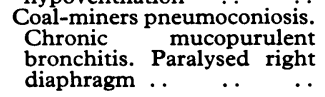 & 1.2 & 1.7 & 3.0 \\
\hline
\end{tabular}

puncture or through an indwelling brachial artery catheter and analysed immediately with a Radiometer A.M.I. machine (Cases 1-5) or I.L. electrodes (Cases 6-8). Carbon monoxide gas transfer was measured by the single breath method in Cases 1, 3, 4b, 7, and 8, with apparatus modified for patients with low vital capacities, and by the steady state method in Case 6. Spirometry was performed with a water canister spirometer, and each patient had an E.C.G. and chest radiograph before and after exchange transfusion. Haemoglobin, P.C.V., and blood urea were also measured before and after each exchange.

Progressive exercise tests were performed on a cycle ergometer by six patients before and after treatment. In Cases 2, 3, 4b, and 5 the object was to cycle for six minutes each at three increasing loads. In Cases 6 and 8 each load was continued for only one minute as this was found to provide a more satisfactory method for assessing changes. All post-treatment measurements and investigations were performed 3 to 11 days after exchange transfusion.

\section{Results}

The haemoglobin, P.C.V., red cell volume, plasma volume, whole blood volume, and blood viscosity, expressed as mean values for the group before and after exchange transfusion, are given in Fig. 1. Fig. 2 shows the changes in blood volumes

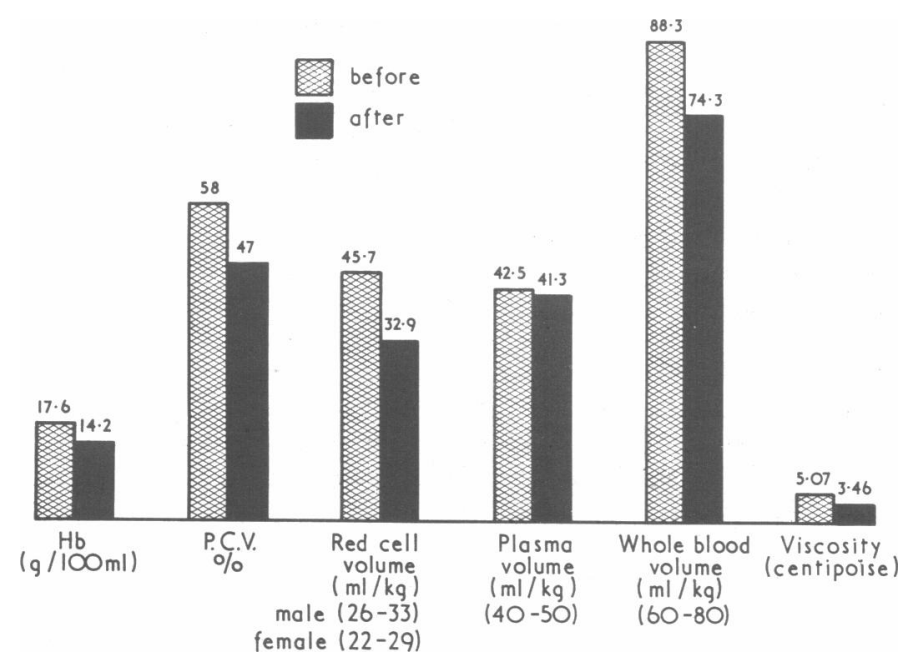

FIG. 1-Mean values of haemoglobin, P.C.V., red cell, plasma, and whole blood volumes, and blood viscosity before and after exchange transfusion. Normal values are given in parentheses.

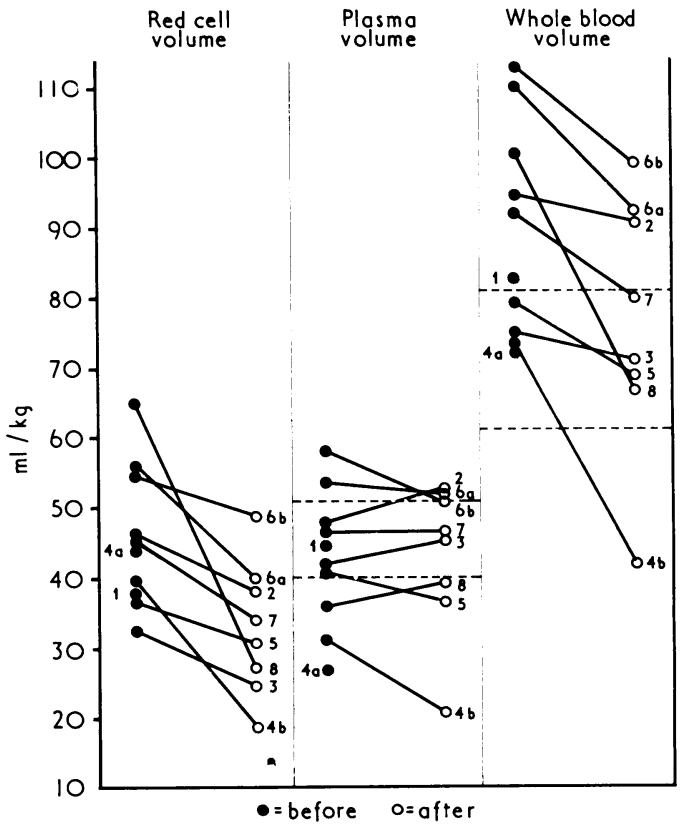

FIG. 2-Individual red cell, plasma, and whole blood volumes before and after exchange transfusion. Normal range for plasma and whole blood volumes lie between the interrupted lines. (In Cases 1 and $4 a$ values only available before treatment.)

with the individual exchanges. All the patients had a raised red cell volume before treatment, but the plasma volumes variedfive had normal values while three had reduced and two had a raised plasma volume. After exchange the fall in whole blood volume resulted largely from the fall in red cell volume except in one patient (Case $4 \mathrm{~b}$ ) in whom exchange transfusion was followed by a prolonged diuresis.

The changes in arterial gas tensions and carbon monoxide gas transfer are shown in Table II. There were no important changes in oxygen tension and no consistent changes in carbon

TABLE II-Values for Arterial Oxygen and Carbon Dioxide Tensions and Carbon Monoxide Transfer Factor before and after Exchange Transfusion in Each Patient

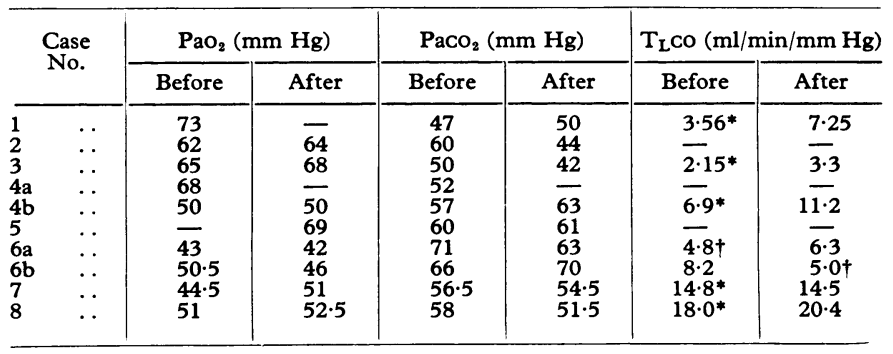

* Measured by single breath method.

† Measured by steady state method.

dioxide tension. All patients had a raised arterial $\mathrm{PCO}_{2}$ before treatment. There were small but insignificant increases in gas transfer in five of the seven patients in whom this was measured.

There were no changes in spirometric volumes, electrocardiograms, or chest radiographs after treatment, nor were there any important or consistent changes in blood urea.

With one exception (Case 5), patients felt subjectively better after every exchange, with an increase in alertness and a relief from headaches if these had been present. They also claimed a subjective increase in exercise tolerance, and this was confirmed objectively in four but not in one other (Case 6a). After exchange transfusion a greater exercise load was performed for longer in Cases 2, 3, 4b, and 8 (Figs. 3 and 4). One patient (Case 5) who derived no subjective benefit from the treatment also showed the least objective improvement of those patients who performed the six-minute progressive exercise tests (Fig. 3). All patients 


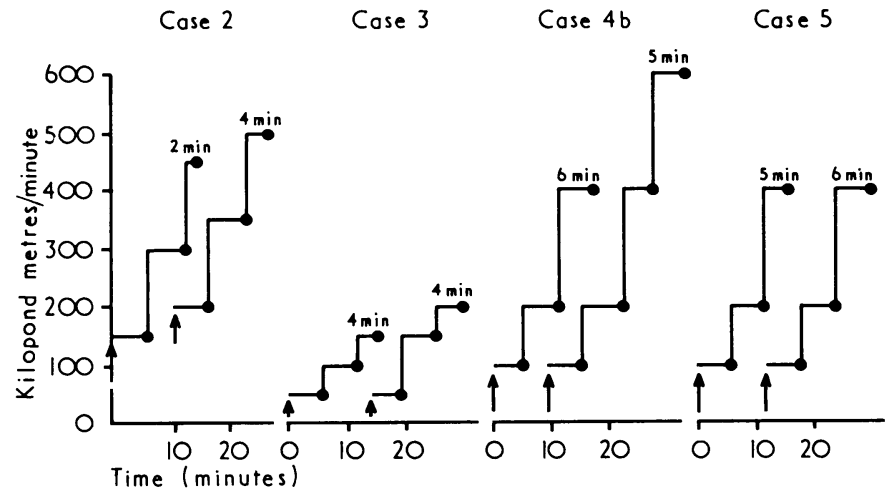

FIG. 3-Results of progressive exercise tests in Cases 2, 3, 4b, and 5 before and after exchange transfusion. (Object was to perform each load for three minutes.) In each case the pretreatment graph is on the left.
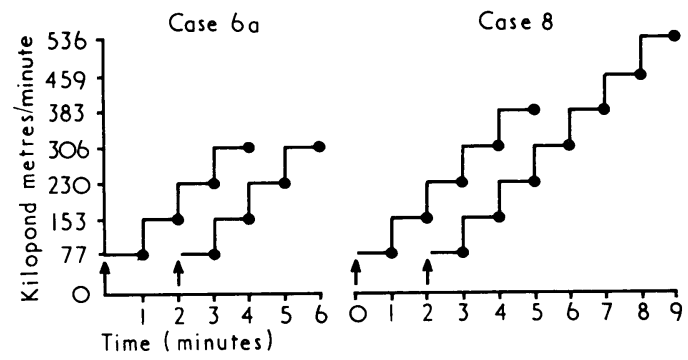
FIG. 4-Results of progressive exercise tests in Cases $6 \mathrm{a}$ and 8 before and
after exchange transfusion. (Each load was performed for one minute.) In each case the pretreatment graph is on the left.

ceased pedalling because of exercise dyspnoea, and no exercise was stopped because of disproportionate tachycardia or dysrhythmia.

There were no adverse reactions to exchange transfusion, though several patients felt rather tired for 24 hours. Two patients (Cases 4 and 6) were readmitted for further exchange transfusions after six and two and a half months respectively and benefited as much from these as they had from their first. One patient (Case 2) was readmitted six weeks after exchange transfusion and died from cardiac and respiratory failure.

\section{Discussion}

The polycythaemia in patients with hypoxic lung disease is similar to the physiological response to hypoxia of normal subjects living at high altitudes. The red cell mass in both groups increases linearly with the fall in arterial oxygen saturation (Shaw and Simpson, 1961) and exponentially as arterial oxygen tension falls (Hume, 1968). This increase may initially be beneficial because of increased oxygen-carrying capacity, since capacity increases linearly with increasing haemoglobin and P.C.V. Blood viscosity, on the other hand, increases exponentially with increasing P.C.V., rising very rapidly at over $60 \%$ (Dintenfass and Read, 1968), and a point may therefore be reached at which further increases in red cell volume will not result in increased oxygen delivery to the tissues because of increasing viscosity and decreasing tissue blood flow. Dintenfass and Read also argued that hypoxia and acidosis may markedly increase blood viscosity at any P.C.V., and this will be an important additional factor in patients with hypoxic lung disease.

Polycythaemia imposes an additional strain on the heart in patients with pulmonary disease. Renzetti et al. (1966) found the incidence of right heart failure to be $53.8 \%$ in patients with P.C.V. over $54 \%$ but only $16.4 \%$ in patients with P.C.V. below $54 \%$, and Mitchell et al. (1964) reported the adverse effect of a high P.C.V. on prognosis. Semmens (1971) found in necropsy studies on patients with chronic airways obstruction that all those with P.C.V. over $51 \%$ have right ventricular hypertrophy. There are several causes of right heart strain in these patients with lung disease, including increased pulmonary vascular resistance due to structural damage, hypoxia, and polycythaemia. These three factors contributing to raised pulmonary vascular resistance are clearly interrelated, but the isolated effect of P.C.V. has recently been found in dogs where pulmonary vascular resistance was shown to increase exponentially with increasing P.C.V. (Agarwal et al., 1970). Other studies in dogs have shown that cardiac output falls as P.C.V. is increased (Sunder-Plassman et al., 1970). Segal and Bishop (1966, 1967) showed that in patients with primary or secondary polycythaemia cardiac output at rest and on exercise increases from subnormal levels as P.C.V. is reduced, provided that blood volume is not markedly decreased by the treatment.

There are good theoretical, clinical, pathological, and experimental reasons therefore for supposing that a high P.C.V. and blood viscosity in patients with hypoxic lung disease may be harmful and that reducing red cell mass in patients with secondary polycythaemia might be beneficial. Our results confirm that most patients with secondary polycythaemia benefit symptomatically from a reduction in red cell mass. Exercise tests mirrored the improvement in subjective exercise tolerance in four patients but not in one other. There were no changes in spirometry and no consistent changes in blood gas tensions, though transfer factor did increase in five of the seven patients in whom it was measured, as it did in four patients of Chamberlain and Millard (1963).

There is a poor correlation between red cell volume and P.C.V. in patients with secondary polycythaemia, because the plasma volume may be raised, normal, or low, as it was in our patients. Pseudopolycythaemia may also occur in patients with lung disease. Therefore it is difficult to suggest a level of P.C.V. above which exchange transfusion is of benefit. We believe it to be of value in patients with a P.C.V. over $60 \%$. All our patients in this group (Cases 4a, 4b, 6a, 7, and 8) improved symptomatically and were enthusiastic about the improvement. We also think that when the red cell volume is raised in patients with P.C.V. over $55 \%$ exchange transfusion should be performed, as it was with benefit in Case $6 \mathrm{~b}$. In three of our patients the P.C.V. was between $50 \%$ and $55 \%$. Each had a raised red cell volume and exchange transfusion benefited two (Cases 1 and 2), and in Case 2 the subjective increase in exercise tolerance was mirrored by an objective increase on the cycle ergometer. One patient (Case 5) did not improve. We conclude that some patients with P.C.V. between $50 \%$ and $55 \%$ who are truly polycythaemic will benefit from exchange transfusion. One of the female patients (Case 3) had a P.C.V. of $48 \%$ with a red cell mass of $32.5 \mathrm{ml} / \mathrm{kg}$. She remained so disabled after several weeks of physiotherapy, antibiotics, diuretics, and digoxin that a 1-litre exchange was performed. She improved both subjectively and objectively.

When P.C.V. and red cell mass are reduced to normal by exchange transfusion we have not had to perform a second exchange before six months. The P.C.V. and red cell mass were still raised after exchange in Case 6 and the patient was readmitted after 10 weeks with an exacerbation of heart failure, and further exchange transfusion was performed. We are now exploring the use of nocturnal oxygen at home to determine whether this will reduce the rate of increase in red cell volume and P.C.V.

We have observed no complications of elective exchange transfusions with dextran 40 in patients with polycythaemia secondary to severe lung disease. Because of the reports of acute renal failure in patients who have received dextran 40 we have not used it in exchange transfusions in patients with a raised blood urea. Another important practical result of a large venesection is iron depletion, and we give all our patients iron by mouth for a long period. Two patients (Cases 6 and 8 ) who had hypochromic polycythaemia initially have required infusions of iron dextran to replace the iron removed by the venesection. 


\section{Conclusion}

The mortality rate in patients with polycythaemia secondary to hypoxic lung disease rises with decreasing $\mathrm{FEV}_{1}$ (Renzetti et al., 1966; Burrows and Earle, 1969), and patients with an FEV below 0.751 . have a five-year survival rate of only $25 \%$. Hypercapnia and cardiac abnormalities affect prognosis adversely independently of their relation to air flow obstruction, and Baldwin et al. (1949) found that the four-year mortality of patients with cor pulmonale was $73 \%$. All our patients are therefore in the poor-prognosis group. We consider that exchange transfusion is a rapid and safe method of reducing red cell mass, P.C.V., and blood viscosity and that this produces a worth-while amelioration of symptoms lasting about six months, after which exchange transfusion can be repeated.

We should like to thank Drs. N. C. Oswald and F. H. Scadding for helpful discussion and constructive criticism and for allowing one of us (B.D.W.H.) to study patients under their care. It is a pleasure to acknowledge the help of the hospital physics department, Guy's Hospital; of Dr. V. R. McCready and Miss J. Lawford, of the diagnostic isotopes department, Royal Marsden Hospital, who performed the blood volume measurements; of $\mathrm{Mr}$. $\mathrm{K}$. Twinn, of the physics department, Guy's Hospital Medical School, who performed the blood viscosity estimations; and of Miss J. Hibbert for her invaluable secretarial help.

\section{References}

Agarwal, J. B., Paltoo, R., and Palmer, W. H. (1970). fournal of Applied Physiology, 29, 866 .

Auchincloss, J. H., and Duggan, J. J. (1957). American fournal of Medicine, $22,74$.

Baldwin, E. de F., Cournand, A., and Richards, D. W. (1949). Medicine, $28,201$.

Burrows, B., and Earle, R. H. (1969). New England fournal of Medicine, 280, 397 .

Chamberlain, D. A., and Millard, F. J. C. (1963). Quarterly fournal of Medicine, 32, 341.

Dintenfass, L., and Read, J. (1968). Lancet, 1, 570

Dintenfass, L., and Read, J. (1968). Lancet, 1, 570.

Gregory, R. J. (1971b). Acta Medica Scandinavica, 189, 551.

Hume, R. (1968). British fournal of Haematology, 15, 131

Laws, J. W., and Heard, B. E. (1962). British fournal of Radiology, 35, 750. Medical Research Council. (1965). Lancet, 1, 775.

Mitchell, R. S., Webb, W. C., and Filley, G. F. (1964). American Review of Respiratory Diseases, 89, 878.

Pengelly, C. D. R. (1966). Lancet, 2, 1381.

Pengelly, C. D. R. (1969). Postgraduate Medical Fournal, 45, 583.

Renzetti, A. D., McClement, J. H., and Litt, B. D. (1966). American fournal of Medicine, 41, 115.

Segal, N., and Bishop, J. M. (1966). Fournal of Clinical Investigation, 45, 1555. Segal, N., and Bishop, J. M. (1967). Clinical Science, 32, 527.

Semmens, J. M. (1971). M.D. Thesis, London.

Shaw, D. B., and Simpson, T. (1961). Quarterly fournal of Medicine, 30, 135.

Sunder-Plassman, L., Klövekorn, W. P., Holper, K., Hase, U., and Messmer, K. (1970). Sixth Conference of the European Society for Microcirculation, Aalberg.

\title{
Influence of Blood Viscosity on Blood Flow and the Effect of Low Molecular Weight Dextran
}

\author{
JOHN A. DORMANDY
}

British Medical fournal, 1971, 4, 716-719

\section{Summary}

Changes in whole blood viscosity are related to changes in the leg blood flow during infusions of low-molecularweight dextran and Hartmann's solution. A close inverse correlation exists between changes in viscosity and blood flow, the change in blood flow being about three times greater than the change in blood viscosity. The dextran and Hartmann's solution had a similar effect on blood viscosity and blood flow if corrections are made for the difference in haemodilution.

\section{Introduction}

There are three basic determinants of peripheral blood flow: the perfusion pressure, the morphology of the vessels, and the viscosity of the blood. In the past attention has been focused almost exclusively on the first two. In more recent years an abnormally high blood viscosity has been found in a number of vascular and haematological diseases (Wells, 1966; Skovborg et al., 1968; Dintenfass, 1969; Dormandy, 1970). An abnormality of blood viscosity, rather than pathological changes in the vessels or the heart, may well be the more important aetiological factor in many diseases characterized by poor circulation. However, the exact relationship, in humans,

\footnotetext{
Royal Free and Royal Northern Hospitals, London

JOHN A. DORMANDY, F.R.C.s., Senior Surgical Registrar, also Honorary Lecturer, Institute of Basic Medical Sciences, Royal College of Surgeons
of England
}

between changes in the blood viscosity and blood flow has rarely been studied; it was one of the aims of the present investigation to measure this relationship.

Changes in blood viscosity and blood flow were observed during intravenous infusions. One of the solutions used for the infusions was low-molecular-weight (L.M.W.) dextran, which enjoys a considerable vogue as a blood flow improver and has been thought to have a specific effect on blood viscosity. To assess whether this dextran alters blood viscosity simply by haemodilution or by a more specific effect the results were compared with another group of subjects who received an equal volume of Hartmann's solution.

\section{Method}

The whole blood viscosity, packed cell volume (P.C.V.), leg blood flow, as well as the arterial and venous blood pressures were measured in 19 patients receiving intravenous infusions before elective abdominal surgery. Patients with evidence of haematological or cardiovascular disease, on history or examination, were excluded from the study. Ten patients received $10 \%$ dextran in saline and 10 Hartmann's solution. One patient was given both solutions at different times. Measurements were made after premedication and before induction of anaesthesia. Initial readings, begun 60 minutes after premedication with papaveretum and scopolamine or pethidine and atropine, were repeated until a steady state had been reached, when a sample of venous blood was withdrawn and an intravenous infusion set up in the arm. Then $500 \mathrm{ml}$ of the solution to be infused was given over a period of 10 to 20 minutes. At the end of the infusion another $10-\mathrm{ml}$ venous blood sample was withdrawn and all the measurements were repeated. Further readings were taken 10 minutes later. 